\title{
Performance Indicators of Vehicle Use in the Transportation Process
}

\author{
Khalikhul Sh. Choriev* \\ Tashkent Institute of Design, Construction and \\ Maintenance of Automotive Roads \\ Tashkent, Uzbekistan
}

Received 02.05.2020, received in revised form 10.08.2020, accepted 14.09.2020

Abstract. The article deals with the connection with the complexity of the design of the car, the diversity of some of its properties and design features, as well as their various combinations and dependences on the operating conditions and type of transportation, because it is difficult to evaluate the car by means of one general indicator. Therefore, in this article, the recommended car quality has been determined by the complex of its most indicative operational properties: capacity using mass, speed, passing ability, safety, etc.

Keywords: Efficiency, operation, car, indicator, technical and operational properties, safety.

Citation: Choriev Kh.Sh. Performance indicators of vehicle use in the transportation process, J. Sib. Fed. Univ. Eng. \& Technol., 2020, 13(6), 766-771. DOI: 10.17516/1999-494X-0265

\section{Показатели эффективности \\ использования автомобиля \\ в процессе транспортировки}

Х.Ш. Чориев

Ташкентский институт по проектированию, строительству и эксплуатации автомобильных дорог

Узбекистан, Ташкент

Аннотация. В связи со сложностью конструкции автомобиля, разнообразием рассмотрены некоторые его свойства и особенности, а также различные их сочетания, зависящие от условий эксплуатации и вида перевозок. Оценить автомобиль одним обобщающим показателем

(C) Siberian Federal University. All rights reserved

This work is licensed under a Creative Commons Attribution-Non Commercial 4.0 International License (CC BY-NC 4.0).

* Corresponding author E-mail address: transportlogistikasi@mail.ru 
довольно трудно. Поэтому рекомендовано определять качество автомобиля комплексом наиболее показательных его эксплуатационных свойств: емкостью массы, скоростью движения, проходимостью, безопасностью и др.

Ключевые слова: эффективность, эксплуатация, автомобиль, свойства, техникоэксплуатационный, безопасность.

Цитирование: Чориев, Х.Ш. Показатели эффективности использования автомобиля в процессе транспортировки / Х.Ш. Чориев // Журн. Сиб. федер. ун-та. Техника и технологии, 2020. 13(6). C. 766-771. DOI: 10.17516/1999-494X-0265

The efficiency of using cars is determined by technical and operational indicators. When analyzing the efficiency of the transportation process, the main indicator is the performance of the rolling stock. Productivity is formed based on several technical and operational indicators that characterize different aspects of road transport. Each of these indicators is influenced by various factors (organizational, economic, technical, etc.), which can affect the indicators themselves, and therefore the performance of cars (Fig. 1).

The efficiency of using a car depends on its quality. Quality is a set of properties that determine the degree of suitability of the car to perform specified functions when used for its intended purpose. The degree of suitability of the vehicle during operation varies.

Due to the complexity of the car's design, the variety of some of its properties and structural features, as well as various combinations of them, different dependencies on the operating conditions and type of transportation, it is quite difficult to evaluate the car by means of one generalizing indicator. Therefore, the quality of the car is determined by the complex of its most significant operational properties: capacity, mass, speed, passing ability, safety, etc.

The efficiency of using cars is described by a system of indicators that can be divided into private and generalizing ones.

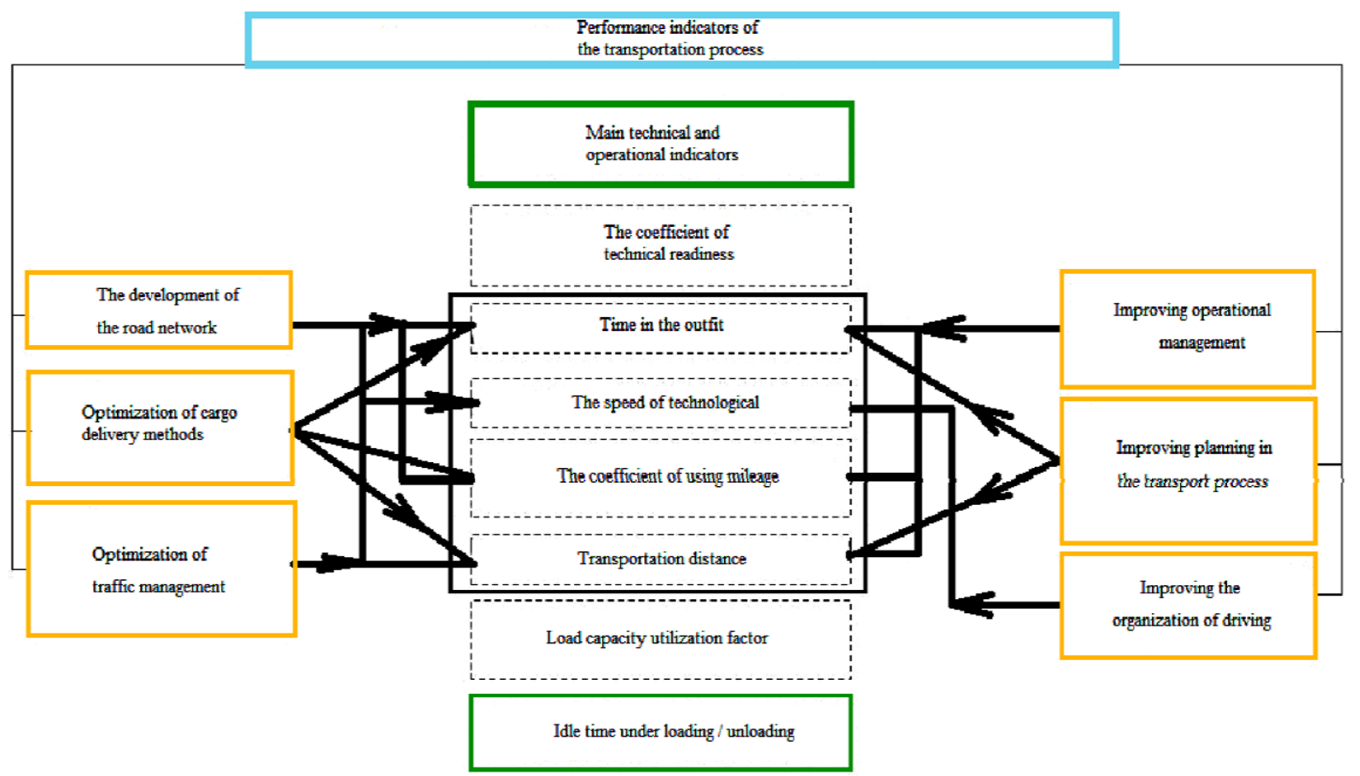

Fig. 1. Factors affecting the performance of the transportation process 
Private ones are technical and operational indicators, which include [1]:

o average number of vehicles;

o composition of vehicles by type, make and number of days of operation of the rolling stock;

o time in the outfit;

o working mileage of the vehicle;

o driving time of vehicles on the route;

o technical readiness coefficient;

o vehicle fleet utilization rates, working hours, and mileage.

Generalizing indicators characterize the influence of many factors in the aggregate on the efficiency of car use. The system of these indicators includes:

$\checkmark$ technical and operational indicators (traffic volume, passenger turnover, vehicle fleet performance);

$\checkmark$ efficiency (cost of transportation, profit and profitability).

Vehicle efficiency refers to the level of performance and the degree of use of vehicles. Car performance indicators include:

o daily and annual output per 1 vehicle;

o number of days worked;

o time when vehicles are in gear and in motion;

o park utilization rate in dress and movement;

o fleet utilization rate on the line;

o the utilization factors of the mileage.

These indicators are applicable for evaluating current and annual vehicle usage estimation.

The main technical and operational indicators of vehicle operation are: technical readiness of the rolling stock, production on the line, use of the rolling stock and the duration of its operation, etc.

Analysis of the performance of freight and passenger transport shows that the greatest impact on performance is the time in the outfit and the average speed of the car.

The factors affecting the performance of the car

For freight transport:

$$
\begin{aligned}
& Q=\frac{{ }^{q \gamma T}{ }_{H} \beta V}{T}, \\
& T_{H}=t_{d v}+t_{p r} \\
& V=\frac{L}{t_{d v}} .
\end{aligned}
$$

For passenger transport:

$$
\begin{aligned}
& P_{p}=T_{H} V_{e} \beta g_{v} \gamma_{v} A_{s p} \alpha_{v} Д_{\kappa} \\
& T_{H}=T_{m}+T_{o} \\
& V_{e}=\frac{L_{s u t}}{T_{H}} .
\end{aligned}
$$


The time the car is in the vehicle's attire ( $\mathrm{Tn}$ ) is determined by the number of hours from the moment the car leaves the motor transport company until it returns to the Parking lot, except for the time of rest and lunch for the driver.

$$
\mathrm{T}_{\mathrm{H}}=\mathrm{T}_{\text {дв }}+\mathrm{t}_{\text {пр }}=\mathrm{T}_{\mathrm{M}}+\mathrm{t}_{0}
$$

where $T_{D V}$ is the driving time of the car; $T_{P R}$ - idle time of the vehicle under loading/unloading; $T_{M}-$ vehicle operating time on the route; $\mathrm{T}$ - time zero of the run.

Vehicle speeds are divided into technical, operational, and message speeds.

Technical vehicle speed $\left(\mathrm{V}_{\mathrm{T}}\right)$ includes all short temporary stops associated with traffic:

$$
V_{T}=\frac{L}{T_{d v}}
$$

where $\mathrm{L}$ is the distance traveled.

The operating speed of a vehicle (Ve) is the conditional speed of the vehicle during its stay on the line:

$$
V_{T}=\frac{L}{T_{m}}=\frac{L}{T_{d v}+t_{p r}+T p t}
$$

where $\mathrm{T}_{\mathrm{PT}}$ is the downtime of the vehicle for technical reasons.

According to these formulas for $\mathrm{Q}$ and $\mathrm{P}$, you can increase the efficiency of the vehicle use by increasing the mileage and load capacity utilization factors, increasing the load capacity, and increasing the average daily mileage of the vehicle, which depends on the technical speed of the vehicle and the downtime during loading and unloading.

As a result of the analysis of technical and operational indicators of the transportation process, those indicators that mainly depend on the parameters of the road, traffic flow and affect the performance of the car.

The efficiency of the transportation process depends on the speed of delivery. The cost of cargo transportation and the amount of inertia in the transportation process are affected by changes in the technical speed of the vehicle. The inertia of the transportation process is a mismatch between the transportation capacity of the transportation complex and the existing amount of cargo flow. The costs that appear in connection with the identification of the inertia of the transport process can be determined [2]:

$$
R=\left[1-\frac{1+\frac{{ }^{l_{e g}}}{{ }_{{ }_{p r} V_{T} \beta_{e}}}}{1+\frac{{ }_{e g}}{{ }^{t_{p r} V_{T f} \beta_{e}}}}\right] .
$$

Due to the increased costs of the transportation process, it is necessary to consider the impact of indicators of the road network on the speed of cargo transportation.

The main indicators that assess the traffic congestion of the road network are the speed, density and intensity of traffic flow. The relationship between the density and speed of traffic flow is expressed in the Greenshields model [3]: 


$$
V=V_{o}\left(1-\frac{k}{k_{c}}\right)
$$

where $V$ - is the maximum possible speed on the road; $V_{0}$ - speed of free movement of cars in the stream; $k$-flux density; $k_{c}$ - maximum flow density that causes all cars in the stream to stop completely.

In mathematical form, the relationship between the intensity and speed of traffic flow is represented by the following models [3]:

$$
N=k_{c} V\left(1-\frac{V}{V_{o}}\right)
$$

where $N$ - the intensity of the traffic.

$$
N=V_{o} k\left(1-\frac{k}{k_{c}}\right)
$$

In this mathematical model, the traffic load of the road network is shown as $k / k_{c}$. These models allow you to estimate the intensity and speed of traffic flow in any city, both on main roads and on roads with low traffic intensity.

The efficiency of the transport process includes the performance of the transport process and traffic safety. A comprehensive indicator for evaluating the efficiency of the transport process should be measurable in real conditions of traffic flow and have a cost expression.

The transport process management system uses a whole set of different indicators that can be of crucial and secondary importance:

- capacity of the road network;

- parameters of the road network;

- the intensity of the traffic flow;

- transport delays;

- your average speed;

- travel time;

- number of vehicle stops;

- the length of the queues in front of intersections;

- the number and severity of road accidents (accidents); the degree of pollution of the environment;

- the level of noise generated by vehicles (vehicles).

The above indicators are related, but the type of dependencies among most of them is not defined. Some of the indicators are determined by collecting and analyzing statistical data [1, 4].

The calculation of certain indicators is made based on the purpose of the assessment. Many of the indicators are determined in the aggregate. When calculating economic efficiency, many indicators are taken into account in monetary terms. When setting the optimization problem, it is usually sufficient to determine a small number of indicators, since it is known that minimizing one parameter that affects the efficiency of the transportation process affects others. For example, when traffic delays are reduced, the speed of traffic flow increases, and traffic time, gas pollution, and noise are reduced accordingly.

When analyzing the car's performance indicators, you must select the leading one. The effectiveness of the transport system is most clearly shown by the work of intersections on the road network. The 
throughput of intersections can be crucial in determining the performance of the transport system as a whole.

The main indicators that need to be determined when analyzing the performance of intersections are the average delay time of vehicles and the average service time of the intersection. When determining transport delays, you can use one of the many known techniques. You can also calculate the vehicle delay time in monetary terms.

There is an indirect relationship between the value of the average transport delay and the degree of traffic safety, since reducing the number and duration of vehicle delays on the route leads to a decrease in the psychological fatigue of drivers, which leads to a decrease in the probability of road accidents.

\section{References}

[1] Gorev A.E. Cargo road transport. Moscow: "Academy", 2008. 288 p.

[2] Velmozhin A.V., Gudkov V.A., Mirotin L.B., Kulikov A.V. Freight transport by road. Textbook. M: Hot Line-The Telecom, 2006. 560 p.

[3] The iNOS. H. traffic Management. Moscow: Transport, 1983. 248 p.

[4] Klinkowski G.I. Organization of road traffic. Moscow: Transport, 2001. 247 p.

[5] http://google.uz/

[6] https://mail.yandex.ru/?win=267\&clid=2100778-003 